www.jmscr.igmpublication.org Impact Factor 5.244

Index Copernicus Value: 83.27 ISSN (e)-2347-176x ISSN (p) 2455-0450 crossref DOI: https://dx.doi.org/10.18535/jmscr/v5i1.25

\title{
Cytopathology of Soft Tissue Tumors with Their Varying Presentation
}

\author{
Authors \\ Dr Sharath Kumar H.K ${ }^{1}$, Dr Gayathri M.N², Dr Shailaja M.D ${ }^{3}$ \\ ${ }^{1}$ Associate Professor, Department of Pathology, Mysore Medical College \& Research Institute, Mysore. \\ ${ }^{2}$ Assistant Professor, Department of Pathology, Mysore Medical College \& Research Institute Mysore. \\ Email:drgayathri1967@gmail.com \\ ${ }^{3}$ Postgraduate, Department of Pathology, Mysore Medical College \& Research Institute, Mysore \\ Email: mdjeyashailaja@yahoo.co.in \\ Corresponding Author \\ Dr Sharath Kumar H.K \\ Associate Professor, Department of Pathology \\ Mysore Medical College \& Research Institute, Mysore \\ Email: sharath_hk@hotmail.com,09743813949
}

\begin{abstract}
Background: Soft tissue tumors continue to challenge clinicians due to their unique character, the infrequency of their occurrence and the difficulties in predicting outcomes. Advances in imaging, as well as improvements in surgical techniques and adjunctive treatment methods, have improved care for patients with these unusual disorders.

Aims and Objectives: Lesion detection and characterization of soft tissue tumors by cytopathology. Methods: The cytological features of soft tissue tumors(STT) are observed, diagnosed and the statistics for the cytopathology are reviewed and compared with literature references.

Results: Of the 2300 cases recorded in our study, 2278(99\%) were diagnosed as benign STT, while $22(1 \%)$ as malignant on cytological examination. The median age of occurrence of benign STT was $3^{\text {rd }}$ decade and that of malignant STT was $4^{\text {th }}$ decade of life. Prevalence was highest in the age group of 20-49 years with male predomoinance.

Conclusion: Fine needle aspiration cytology (FNAC) is a valuable tool in the diagnosis of STT combined with competent imaging and immunocytochemistry. FNAC is rapid and non-invasive technique, which gives diagnostic clues and helps the clinicians in better management of these patients.

Keywords: Soft Tissue Tumors, Cytopathology, Fine Needle Aspiration Cytology.
\end{abstract}

\section{INTRODUCTION}

Non epithelial extra skeletal tissue of the body exclusive of the reticuloendothelial system, glia and supporting tissue of various parenchymal organs are the soft tissue elements and are heterogeneous ${ }^{(4)}$. Soft tissue tumors represent a major group of lesions that are often subtle in presentation and have wide variation in behavior ${ }^{(1,2,3)}$. These are classified on a histogenetic basis. FNA used for diagnosing has the advantage that it is relatively a traumatic and can be used to sample deep-seated tumors under guidance with 
CT scan. FNA minimizes the tumor spillage, and very helpful in diagnosing intra abdominal and retroperitoneal tumors.

Many of the STT have a relationship to normal soft tissue structures so that the lesions may arise in relation to the fascia, elastic tissue, fat, smooth muscle, skeletal muscles, fibrous capsule, blood vessels and nerves. The symptomtology of these tumors may be related in part to the effect they have on the function of the normal tissue adjacent to them.

Masses arising in the subcutaneous and deeper tissues are evaluated by radiologic studies and require biopsy for definite diagnosis and treatment. Clinical evaluation and management of soft tissue masses must emphasize on a team approach incorporating the combined skills of pathologists, radiologists and surgeons with the ultimate goal of improving patient outcome. FNAC, plays a vital role as a preliminary diagnostic tool in distinguishing benign from malignant STT. Our purpose is to provide a frame work for the systematic approach to FNA evaluation of STT.

\section{AIMS AND OBJECTIVES}

1. To study the cytomorphology of soft tissue tumors.

2. To study the distribution of soft tissue tumors.

\section{METHODS}

The study includes 2300 cases and was carried out in the Department of Pathology, Mysore Medical college and Research Institute for a period of five years from Jan-2011 to Dec2015. Cases with soft tissue swelling attending Krishna Rajendra and Chaluvamba Hospital were selected. Aspiration was carried out using a 22gauge disposable needle and 10cc disposable syringe for suction. The wet fixed smears were stained with hematoxylin - eosin (H\&E) and pap stain and a detailed cytological examination was done. The FNAC report was correlated with histopathology report and immunohistochemical stains like vimentin, S100 protein, HMB-45, calretin and CD-34 were done in few cases to confirm the diagnosis.

\section{STATISTICAL ANALYSIS}

Data analyzed, tabulated and statistical techniques like frequency distribution and percentage were calculated and represented with tables charts using $\mathrm{R}$ software.

\section{RESULTS}

Of the 2300 cases recorded in our study, 2278 (99\%) were diagnosed as benign STT, while $22(1 \%)$ as malignant on cytological examination. The median age of occurrence of benign STT was $3^{\text {rd }}$ decade and that of malignant STT was $4^{\text {th }}$ decade of life ${ }^{(5,6)}$. Prevalence was highest in the age group of 20-49 years with male predominance $^{(5,7)}$.

Table 1 shows the Distribution of Soft Tissue Tumors (2300 cases)

Lipoma was the commonest tumor in our study. Fibrous histiocytomas were the next common tumors followed by hemangiomas and Schwannomas. Benign spindle cell tumors in this series comprised of tumors whch were more neurogenic in origin and few were benign fibrous tumors. Neurogenic tumors were mainly schwannomas and neurofibromas,

This series showed highest incidence of malignant fibrous histiocytoma and liposarcoma which could be diagnosed on cytological features alone. 2 cases of rhabdomyosarcoma and one case of leiomyosarcoma were found in our study.

Two cases in our study posed problems in diagnosis and required extensive workup. These cases are presented here briefly to highlight the need for multidisciplinary approach in diagnosing soft tissue tumors in some cases.

Case 1: A 35 year old male presented with history of dyspnoea. On examination clinician noticed multiple swellings over the body and referred to cytopathology section. There were well defined nodules over the left upper extremity and face. FNAC from all the nodules showed 


\section{JMSCR Vol||05||Issue||01||Page 15350-15354||January}

similar cytomorphology (fig 1), Smears were cellular and showed spindle shaped cells with elongated nuclei, vesicular chromatin and moderate cytoplasm. On cytology only a diagnosis of spindle cell lesion could be made. On radiology a lesion in lung was detected with metastasis to pleura. Lung biopsy shiwed features of malignant mesothelioma, Both lung biopsy and nodule excision biopsy showed calretin positivity. The final diagnosis was malignant mesothe-lioma of biphasic type.

Case 2: 55 years female presented with recurrent exophytic grey white ulcerated mass over the right medial malleolus (fig 2) previously diagnosed as Neurilemmoma. There were multiple nodules of varying sizes, soft in consistency along the course of right peroneal nerve and inguinal region measuring $3 \times 2 \mathrm{cms}$.

FNA from the inguinal swellings thought to be lymph nodes were highly cellular and composed of plump cells with spindle nuclei and abundant cytoplasm amidst a few pleomorphic cells(fig 3) and fibrillar stromal fragments seen against a myxoid background. It was diagnosed as Ancient Neurilemmoma on cytology and as benign fibrous histiocytoma on histopathology. However, immunohistochemistry showed positivity for S-100 protein(fig 4) and HMB-45 (fig 5). The final diagnosis of this case was Clear cell sarcoma.

Fig 1- FNAC of Spindle cell tumor

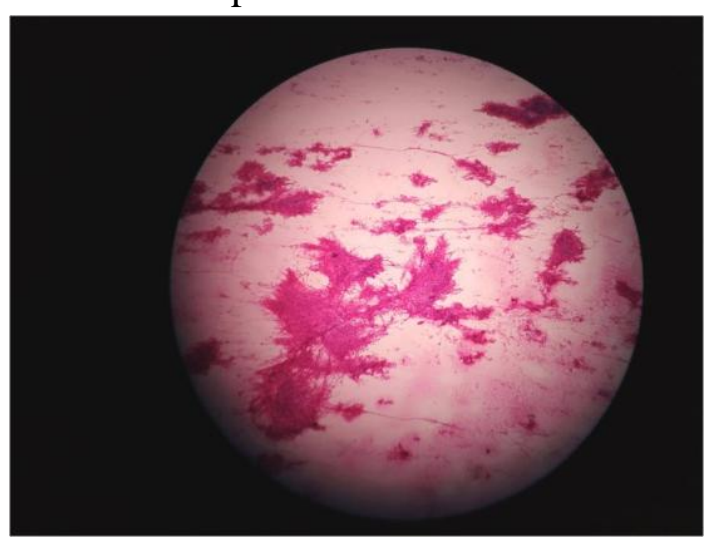

Fig 2- Ulceroproliferative growth over the right medial malleolus with enlarged ingunial lymph node

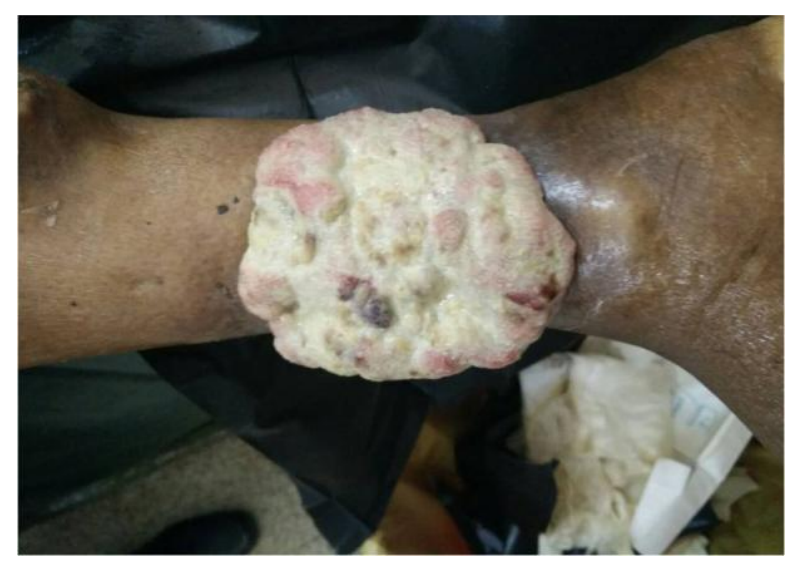

Fig 3- FNAC of Ancient Schwannoma

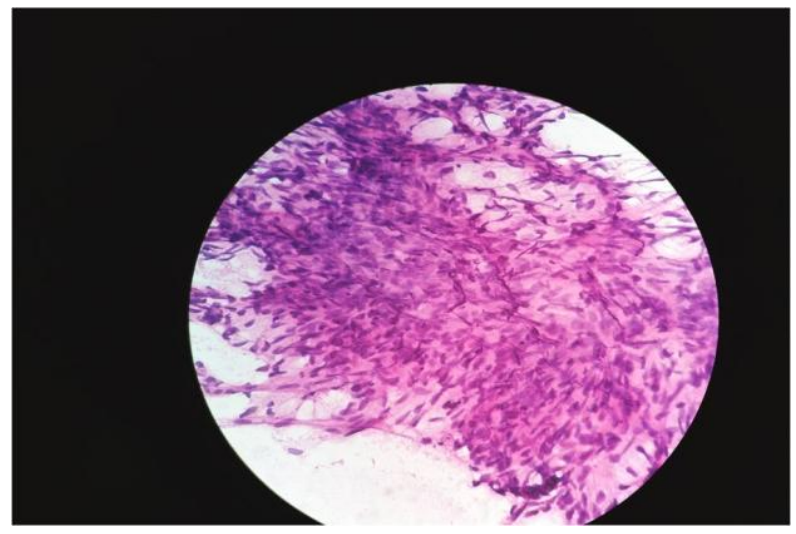

Fig 4- S100(200): Immunoreactivity

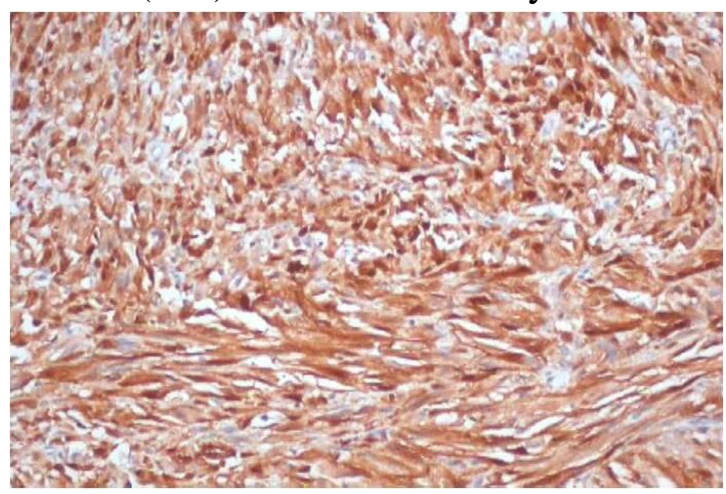

Fig 5- HMB45(X200): Immuno reactivity

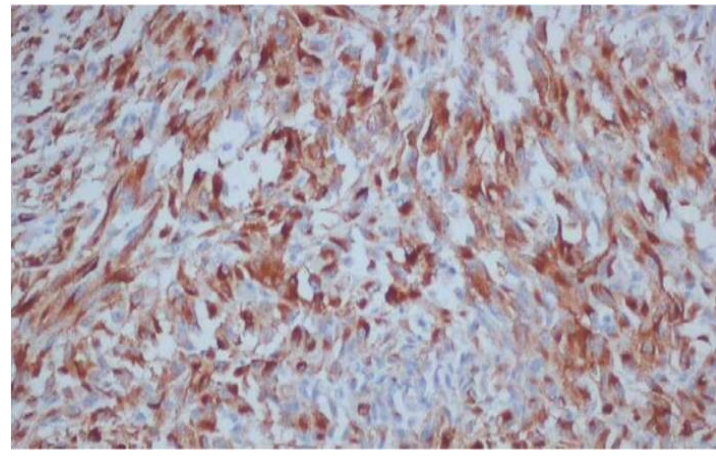


Table 1- Shows the Distribution of Soft Tissue Tumors (2300 cases)

\begin{tabular}{|l|ccc}
\hline Benign Lesions [2278 cases] & Number of cases & Percentage(\%) \\
\hline Lipoma and its variants & 1380 & $60 \%$ \\
\hline Fibrous histiocytoma & 460 & $20 \%$ \\
\hline $\begin{array}{l}\text { Benign spindle cell tumors(non } \\
\text { specific) }\end{array}$ & 253 & $11 \%$ \\
\hline Neurogenic & 23 & $01 \%$ \\
\hline $\begin{array}{l}\text { PVNS/GCTTS(giant cell tumor } \\
\text { tendon sheath) }\end{array}$ & 06 & $0.26 \%$ \\
\hline Vascular lesions & 156 & $07 \%$ \\
\hline$\quad$ Malignant Lesions [22 cases] & & $32 \%$ \\
\hline Malignant fibrous histiocytoma & 07 & $27 \%$ \\
\hline Dermatofibrosarcoma protuberance & 06 & $27 \%$ \\
\hline Liposarcoma & 06 & $09 \%$ \\
\hline Rhabdomyosarcoma & 02 & $04 \%$ \\
\hline Leiomyosarcoma & 01 & \\
\hline
\end{tabular}

\section{DISCUSSION}

FNAC has become an established tool as a diagnostic tool in many clinical conditions. It is one of the important frontiers in evaluation of soft tissue tumors ${ }^{(7,11)}$. It was found that there were false negative cases - 3 cases of lipoma that were later diagnosed as well differentiated liposarcoma on histopathology, cases of fibromatoses were later diagnosed as fibrosarcoma on histopathology and cytological diagnosis of benign spindle cell tumor were turned out to be low grade fibromyxoid sarcoma on histopathology which is similar to the study conducted by Kulkarni etal. In the present study ancient schwannoma was diagnosed as Clear cell sarcoma after immunohistchemistry. Our study compares well with Priyanka et al and others in the distribution of both benign and malignant tumors lipoma being the commonest benign tumor and malignant fibrous histiocytoma being commonest malignant tumor ${ }^{(5)}$.

FNAC of STT sometimes results in inadequate sampling of the tumor due to blood contamination. The individual cells are dispersed leading to partial loss of recognizable diagnostic pattern this results in less specificity for diagnoses, which is similar to the observation made by Nagira $\mathrm{K}$ etal. It is difficult, in some cases, to distinguish benign cellular lesions from borderline tumors and low grade sarcomas. Cytomorphologic features of fibrosarcomas are difficult to distinguish from fibromatoses ${ }^{(12,13)}$. Also, in densely collagenised or sclerotic or vascular or cystic lesions, FNAC yields sparse cellularity making diagnosis difficulty. In such case diagnosis can be made only on histopathology.

In our study we would like to emphasize that diagnosis of STT by FNAC requires cooperation and interaction between the pathologist, surgeon and radiologist. Diagnosis of STT could be strengthened by histological correlation with the help of immunohistochemistry ${ }^{(14,15)}$.

\section{CONCLUSION}

The bulk of reported data and our own practices support the ability of fine needle aspiration cytology to accurately diagnose soft tissue tumors. We can conclude that FNAC is a useful, safe and cost-effective procedure for the evaluation of soft tissue tumors.

\section{ACKNOWLEDGEMENT}

We acknowledge Dr. Bharathi M, Professor \& HOD, Department of pathology, Mysore Medical College and Research Institute, Mysore for her support.

\section{REFERENCES}

1. Kufe DW, Pisters PWT, O 'Sullivan B, Demetri GD, Sarcomas of non osseous tissues. In: Bast RC Jr, Pollock RE, et al. Cancer Medicine. $5^{\text {th }}$ ed. Hamiliton, Ont; Lewiston, NY; Decker; 2000.

2. Weiss SW, Goldblum JR, eds. Enzinger and Weiss's Soft Tissue Tumors $4^{\text {th }}$ ed. Philadelphia, Pa: Mosby; 2001.

3. Sondak VK, Chang AE. Clinical evalution and treatment of soft tissue tumors. In: Weiss SW, Goldblum JR, eds. Enzinger and Weiss's soft tissue tumors. $4^{\text {th }}$ ed. Philadelphia, pa: Mosby; 2001. 
4. Akerman $\mathrm{M}$ and Domanski $\mathrm{H}$, "soft tissues", in Orell and Sterrett,Eds, pp:387-400, Churchill Livingstone, Edinburgh, Scotland, 5 $5^{\text {th }}$ edition, 2012. View at Google Scholar

5. Priyanka BS, Anand KV, Raj KC, and Jitender SN. A Prospective study of Soft Tissue Tumors Histocytopathology correlation. Pathology Research international Vol 2014,Article ID678628, 9 pages.

6. Akerman M, Domanski HA. Cytological Classification of soft tissue tumors based on tha principal pattern. The cytology of soft tissue tumors. Monogr Clin Cytol. 2003; 16: 103-7.

7. Enzinger FM, Weiss SW. Fine needle aspiration cytology. In: Enzinger FM, Weiss SW, eds: Soft Tissue Tumors. $4^{\text {th }}$ ed. St,Louis: MO: Mosby;2001.

8. Kulkarni DR, Kokandakar HR, Kumbhakarna NR, Bhople KS. Fine needle aspiration cytology of soft tissue tumors in correlation with histopathology. Indian J pathol Microbiol,2002; 45(1): 45-8.

9. Nagira $\mathrm{K}$, Yamamoto $\mathrm{T}$, Akisue $\mathrm{T}$, Marui T, Hibra $\mathrm{T}$, et al. Reliability of fine - needle aspiration biopsy in the initial diagnosis of soft tissue lesions. Diagn cytopathol. 2002; 27(6): 354-61.

10. Jergesen HE, Mankin HJ, Schiller AL. Diffuse pigmented villonodular synovitis of knee mimicking primary bone neoplasm. J Bone Joint surg(Am). 1978; 60: 825-829.

11. Palmar HE, Mukunyadzi P, Culbreth W, Thomar JR. Subgrouping and grading of soft tissue sarcomas by fine needle aspiration cytology; a histopathologic correlation study. Diagn cytopathol 2001; 24(5): 307-16.
12. Sapi Z, Antal I, Papai Z, Szendroi M, Mayer A, et al. Diagnosis of soft tissue tumors by fine - needle aspiration with combined cytopathology and ancillary techniques. Diagn cytopathol. 2002; 26(4): 232-42.

13. Wakely PE Jr, Kneisl JS. Soft tissue aspiration cytopathology. Cancer. 2000; 90(5): 292-8.

14. Schmidt D, Harms D. The applicability of immunohistochemistry in the diagnosis and differential diagnosis of maglignant soft tissue tumors. Klin pediatr. 1990; 202(4): 224-9.

15. Rasool Z, Bhat ML, Samoon N, Baba $\mathrm{K}$, Rumana $\mathrm{M}$ et al. Utility of fine needle aspiration cytology in diagnosis of soft tissue lesions with histopathological correlation. Glob J Med Public Health. (GJMEDPH). 2013; 2(2): 1-7. 